\title{
PEMANFAATAN ENTERPRISE ARCHITECTURE PLANNING UNTUK PERENCANAAN STRATEGIS SISTEM INFORMASI AKADEMIK PADA AMIK DIAN CIPTA CENDIKIA PRINGSEWU
}

\author{
Nurmayanti ${ }^{1}$, Prihandoko ${ }^{2}$ \\ ${ }^{1}$ Dosen Teknik Komputer, STMIK Dian Cipta Cendikia Kotabumi \\ ${ }^{1}$ E-mail: nurmayanti89@gmail.com, \\ ${ }^{2}$ Dosen Ilmu Komputer, Universitas Guna Darma \\ ${ }^{2}$ E-mail: prihandoko@gmail.com
}

\begin{abstract}
ABSTRAK
AMIK Dian Cipta Cendikia Pringsewu merupakan Akademik Manajemen Informatika dan Komputer yang menyelengarakan pendidikan dibidang komputer yang harus memiliki perencanaan sistem informasi strategis dalam merencanakan penggunaan teknologi dan sistem informasi pada sekolah tinggi tersebut. Sistem Informasi Akademik merupakan salah satu pondasi utama dalam proses bisnis setiap institusi yang bergerak dibidang pendidikan. Semakin baik sistem akademik tersebut dirancang, maka kualitas kinerja proses pembelajaran akan meningkat serta akan mempengaruhi kinerja sistem-sistem pendukung lainnya.

Metode yang digunakan dalam penelitian ini adalah Enterprise Architecture Planning (EAP) atau kerangka. .

Hasil dari penelitian ini dapat disimpulkan bahwa rencana strategi informasi dari tahapan ini akan menghasilkan sebuah arsitektur enterprise. Adapun hasil dari pendefinisian enterprise ini menghasilkan 61 entitas dan 45 usulan kandidat aplikasi.
\end{abstract}

Kata kunci : Enterprise Architecture Planning, AMIK DCC Pringsewu

\begin{abstract}
AMIK Dian Cipta Cendikia Pringsewu is an Academic of Informatics and Computer Management who conducting computer education which must have strategic information system planning in planning the use of technology and information system at that high school. Academic Information System is one of the main foundations in the business process of every institution engaged in education. The better the academic system is designed, the quality of the learning process performance will increase and will affect the performance of other support systems.

The method used in this research is Enterprise Architecture Planning (EAP) or framework. . The stages of Enterprise Architecture Planning (EAP) begin with the initial stages of planning initiation with Value Chain Tools, understanding current conditions with business modeling and analyzing system conditions, future plans by defining data architecture, application architecture, technology architecture and lastly implementation plan .

The results of this study can be concluded that the information strategy plan of this stage will produce an enterprise architecture. The results of this definition of enterprise produces 61 entities and 45 candidate application proposals.
\end{abstract}

Keywords: Enterprise Architecture Planning, AMIK DCC Pringsewu 


\section{PENDAHULUAN}

Dalam menghadapi persaingan yang terjadi antar perguruan tinggi maka diperlukan beberapa strategi yang tepat seperti membuat target pesaing yang tepat, mengguatkan keunggulan yang dimiliki, mencari kelemahan pesaing, mempelajari permasalahan berdasarkan pengalaman dan mencari jalan keluar dari persaingan. AMIK Dian Cipta Cendikia Pringsewu merupakan Akademik Manajemen Informatika dan Komputer yang menyelengarakan pendidikan dibidang komputer yang harus memiliki perencanaan sistem informasi strategis dalam merencanakan penggunaan teknologi dan sistem informasi pada sekolah tinggi tersebut. Untuk menurunkan kesenjangan tersebut, maka diperlukanlah sebuah paradigma dalam merencanakan, merancang, dan mengelola sistem informasi yang disebut dengan arsitektur enterprise (enterprise architecture). Arsitektur enterprise adalah sebuah pendekatan logis, komprehensif, dan holistik untuk merancang dan mengimplementasikan sistem dan komponens sistem secara bersamaan ( Perizaue, 2002).

Tetapi sampai saat ini AMIK Dian Cipta Cendikia Pringsewu belum memiliki data yang terintegrasi. Sumber daya dan data masih dikelola oleh masing-masing satuan kerja secara terpisah dengan mekanisme dan pola pengelolaan yang berbeda-beda. Hal ini tentu saja sangat berpengaruh terhadap layanan informasi kepada semua pihak yang membutuhkan. Melihat kondisi yang ada saat ini, AMIK Dian Cipta Cendikia Pringsewu sudah saatnya untuk mulai membangun sebuah sistem informasi yang terintegrasi.Untuk membangun sebuah sistem informasi yang terintegrasi dengan baik tentunya diperlukan sebuah rencana sistem informasi yang baik pula, yaitu sebuah rencana yang selaras dengan visi, misi dan kebijakan organisasi.

Pada penelitian oleh Yeni Kustiyahningsih, Seminar Nasional Teknologi 2007 (SNT 2007), ISSN : 19789777 dengan judul Perencanaan Arsitektur Enterprise Berbasis Web Pada Institusi Pendidikan Tinggi. Adanya Roadmap enterprise architecture planning dapat menciptakan suatu sistem yang sistematis untuk mempermudah proses pembuatan dan implementasi sistem informasi teknologi dalam institusi pendidikan tinggi. Arsitektur Enterprise secara sistematis dan lengkap dapat mendefinisikan sistem dan teknologi informasi yang sedang berjalan dan lingkungan sistem informasi yang diperlukan. rsitektur enterprise suatu perguruan tinggi dapat di jadikan sabagai pedoman untuk menentukan kebijakan suatu organisasi terutama bagi pimpinan organisasi (Yeni Kustiyaningsih, 2007).

Penelitian ke dua oleh Agustono Heriadi, M. Suyanto dan Sudarmawan. Citec Journal, Vol. 1, No. 1, November 2013 - Januari 2014, ISSN : 2354-5771 dengan judul Perencanaan Stategis Sistem Informasi STMIK Cahaya Surya Kediri. Berdasarkan strategi bisnis $\mathrm{Si}$, diperlukan visi misi SI/TIyang dapat selaras dengan visi, misi serta tujuan dari STMIK Cahaya Surya Kediri. Berdasarkan strategi manajemen SI/TI, diperlukan restrukturisasi organisasi (penambahan divisi baru yang khusus menangani hal yang berkaitan dengan SI/TI institusi), pengembangan kompetensi SDM SI/TI, dan kebijakan SI/TI agar keberadaan SI/TI pada STMIK Cahaya Surya Kediri tidak menjadi penghambat kegiatan bisnis kampus dan layanan SI/TI dapat terlaksana dengan baik. Berdasarkan strategi SI, dibutuhkan sebanyak dua puluh satu (21) sistem informasi yang sudah dipetakan ke dalam McFarlan Strategic Grid untuk mendukung kegiatan bisnis berupa aktifitas utama pendukung pada STMIK Cahaya Kediri agar proses bisnis menjadi lebih efisien. Berdasarkan GAP Analysis IS, dari dua puluh satu (21) sistem informasi yang diperlukan, sebanyak empat belas (14) sistem informasi harus dibuat baru., tiga (3) sistem informasi memerlukan pengembangan dari sistem yang sudah ada, dan empat (4) sistem informasi yang sudah tersedia pada STMIK Cahaya Surya Kediri. Berdasarkan rencana implementasi, diperlukan waktu setidaknya empat (4) 
tahun supaya perencanaan strategis sistem informasi dapat diimplemetasikan dengan baik (Agustono Heriadi, 2014)

Penelitian ke tiga oleh Ahmad Khumaidi, Agus Suryana dan Eka Ridhawati,Seminar Nasional Teknologi Informasi dan Multimedia 2016, ISSN : 2302-3805 dengan judul Perencanaan Strategi Sistem Informasi Dan Teknologi Informasi Pada Stmik Pringsewu Dengan Menggunakan Metodologi Enterprise Architecture Planning (Eap). Pemodelan bisnis utama yang digambarkan dalam bentuk value chain, memiliki aktifitas utamanya yaitu Penerimaan Mahasiswa, Operasional Akademik, Pelepasan Mahasiswa dan Manajemen Sumber Daya Manusia. Berdasarkan hasil temuan pada organisasi, Sekolah Tinggi Manajemen Informatika dan Komputer (STMIK) Pringsewu mengeluarkan kebijakan perbaikan perangkat sistem informasinya, sehingga sistem yang ada perlu dilakukan pengembangan dan perbaikan. STMIK Pringsewu belum memiliki sistem pengelolaan sumber daya informasi sebagai salah satu acuan untuk merencanakan pengembangan sistem terintegrasi untuk bidang akademik dan pendukungnya. Untuk menentukan urutan aplikasi, prinsip aplikasi yang menciptakan data akan dikembangkan sebelum aplikasi yang menggunakan data tersebut, harus dapat diterapkan sepenuhnya. Urutan aplikasi juga dapat dipengaruhi oleh kebutuhan organisasi, sistem saat ini, manfaat, resiko, biaya atau faktor sukses. Hasil pendefinisian terhadap arsitektur enterprise pada organisasi Sekolah TinggiManajemen Informatika dan Komputer (STMIK) Pringsewu dan disesuaikan dengan batasan masalah pada makalah ini, ditemukan 28 entitas data dan 26 usulan aplikasi (Ahmad Khumaidi, 2016)

Penelitian ke empat oleh Hendra Kurniawan, Jurnal TIM Darmajaya Vol. 01 No. 02 Oktober 2015, ISSN:2442-5567, EISSN:2443-289X dengan judul Penggunaan Enterprise Architecture Planning Dalam Pemodelan Bisnis
Pendidikan Dan Pelatihan. Berdasarkan hasil dalam pemodelan bisnis pada Bandikaltda dapat dijadikan sebagai informasi tentang bagaimana hubungan antara fungsi bisnis/unit bisnis dengan organisasi. Informasi tersebut dapat dijadikan dasar untuk melanjutkan tahapan pada enterprisearchitecture planning meliputi arsitektur data, aplikasi teknologi. Pemodelan bisnistersebut juga dapat dijadikan acuan bahwa fungsi bisnis tersebut memiliki tugas dan tanggung jawab yang tidak terpisahkan dari unit fungsi bisnis yang lainnya (Hendra Kurniawan, 2015)

Penelitian ke lima oleh Rommi Kaestria, Journal Speed - Sentra Penelitian Engineering dan edukasi, Vol 8 No. 3, 2016, ISSN: 1979-9330 dengan judul Perencanaan Strategi Sistem Informasi Pada Sekolah Tinggi Ilmu Komputer.Dengan analisa SWOT yang telah diterapkan maka dihasilkan strategi pembangunan sistem dalam bentuk portofolio aplikasi Portal dan website organisasi sebagai strategi promosi melalui media online. Perlu adanya Sistem Informasi karyawan dan dosen dan sistem informasi keuangan sekolah tinggi, Sistem informasi akademik mahasiswa dan sistem informasi penerimaan mahasiswa baru yang dicapai untuk menghasilkan keuntungan yang relevan. Sistem Informasi perpustakaan yang mungkin menjadi penting untuk mencapai tujuan STMIK Palangkaraya dan penelitian ini menjadisebuah rekomendasi untuk STMIK Palangkaraya sebagai tindakan strategi dalam perencanaan sistem informasi kedepan (Rommi Kaestria, 2016)

Penelitian ke enam oleh Yusup Miftahuddin, Muhammad Ichwan, Mira Musrini, Jurnal Informatika, No.1, Vol. 4, Januari - April 2013, ISSN : 2087-5266, dengan judul Penerapan Metode EAP (Enterprise Architecture Planning) Pada Pembuatan Blueprint Sistem Akademik. Dengan diterapkannya metode Enterprise Architecture Planning (EAP) dalam pembuatan blueprint sistem akademik ITENAS ini, ditemukan aspek-aspek yang 
penting dalam pembuatan blueprint sistem akademik ini. Aspek-aspek tersebut yaitu proses bisnis sistem, pihak-pihak yang terlibat pada sistem, data yang dibutuhkan oleh sistem dan matrikulasi sistem. Pada penelitian ini terdapat 15 pihak yang terlibat pada sistem dan enam matrikulasi seperti proses vs bisnis, proses vs organisasi, dan proses vs kelas data. Berdasarkan tahapan yang telah dilakukan pada penelitian maka metodelogi EAP dapat diterapkan pada pembuatan blueprint sistem akademik ITENAS (Yusuf Miftahudin, 2103)
Berdasarkan penelitian terdahulu maka penulis berinisiatif menggunakan Enterprise Architecture Planning dengan studi kasus perencanaan strategi sistem informasi pada AMIK Dian Cipta Cendikia Pringsewu. Tujuannya adalah untuk menghasilkan rencana strategis sistem informasi pada AMIK Dian Cipta Cendikia Pringsewu dengan menggunakan metodelogi Enterprise Architecture Planning.

\section{METODE PENELITIAN}

Alur penelitian ini dapat di lihat pada gambar 1 berikut ini :

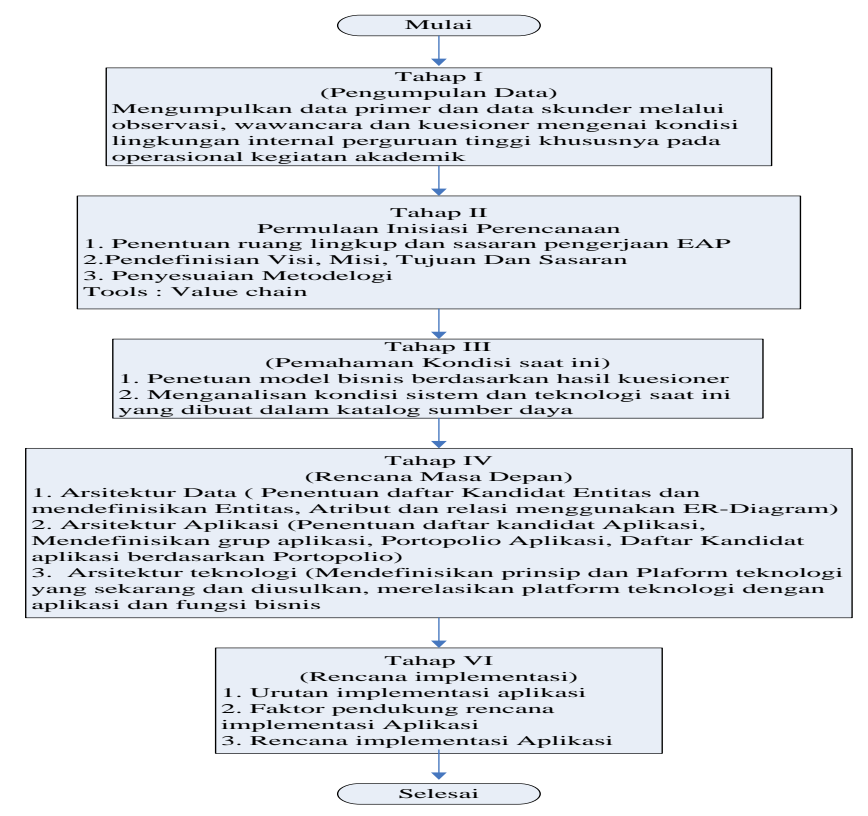

Gambar 1 Alur Langkah Penelitian

\subsection{Landasan Teori}

\subsubsection{Enterprise}

Dibawah ini adalah beberapa pengertian atau definisi mengenai enterprise:

a. Bisnis atau organisasi/perusahaan yang dibentuk untuk menghasilkan produk atau memberikan pelayanan (O'Rouke, 2003).

b. Enterprise juga didefinisikan sebagai keberfungsian seluruh komponen organisasi/perusahaan yang dioperasikan di bawah kepemilikan atau kontrol dari organisasi/perusahaan tunggal. Enterprise dapat berupa bisnis, layanan (service) atau merupakan keanggotaan dari suatu organisasi/ perusahaan, yang terdiri dari satu atau lebih usaha, dan dioperasikan pada satu atau lebih lokasi (Wahyudin Asep, 2009)

\subsubsection{Architecture}

Arsitektur (Architecture) adalah cara dimana sebuah sistem yang terdiri dari network, hardware dan software yang distrukturkan. Arsitektur pada dasarnya menceritakan bagaimana sebuah bentuk konstruksi dalam sebuah sistem, bagaimana setiap komponen sistem disusun, dan bagaimana semua aturan dan interface (penghubung sistem) digunakan untuk 
mengintegrasikan seluruh komponen yang ada. Arsitektur juga mendefinisikan fungsi, deskripsi dari format data dan prosedur yang digunakan komunikasi diantara setiap node dan workstation (Wahyudin Asep, 2009)

\subsubsection{Enterprise Architecture Planning}

Enterprise Architecture Planning adalah proses pendefisian arsitekture dalam penggunaan informasi untuk mendukung bisnis dan rencana untuk mengimplementasikan arsitekture tersebut (spewak 1992).

Definisi ini mengandung tiga kata kunci :

1. Pendefinisian

Ini berarti melakukan pendefenisian arsitektur sistem bukan merancang sistem tersebut. Arsitektur enterprise mendefinisikan arsitektur, sedangkan perancangan sistem merupakan tanggung jawab perancang.

2. Arsitektur

Arsitektur merujuk ke tiga arsitektur yang di definiskan yaitu : arsitektur data, arsitektur aplikasi, arsitektur teknologi.

3. Rencana

Arsitektur mendefinisikan apa yang diperlukan dan rencana mendefiniskan kapan mengimplementasikannya.

Berikut gambar tujuh komponen dan empat lapisan dalam EAP [spewak 1992]

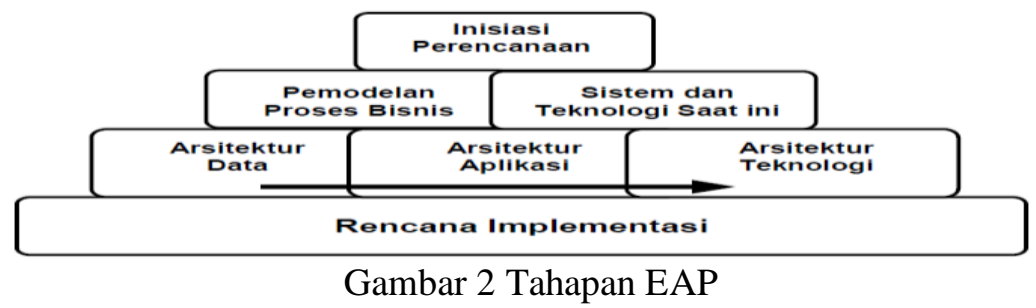

\subsubsection{Lapisan I Permulaan}

Lapisan ini merupakan inisiasi perencanaan yang terdiri dari penentuan metodelogi yang digunakan, siapa yang akan terlibat, dan tools yang akan digunakan. Hasil dari tahapan ini adalah rencana kerja untuk perencanaan arsitektur enterprise dan komitmen manajemen organisasi dan parameter kenrja (Yusuf Miftahudin, 2013).

\subsubsection{Lapisan II Pemahaman kondisi saat ini}

Lapisan ini digunakan untuk memodelkan bisnis. Tahapan ini menggabungkan dan membangun suatu basis pengetahuan mengenai bisnis dan informasi yang digunakan bisnis saat ini. Tahapan ini mendefinisikan sistem aplikasi dan platform teknologi yang ada untuk mendukung bisnis saat ini. Hasilnya berupa inventaris sistem aplikasi data dan platform teknologi yang akan dijadikan dasar untuk rencana migrasi jangka panjang (Yusuf Miftahudin, 2013).

\subsubsection{Lapisan III Rencana masa depan}

Lapisan ini digunakan untuk mendefinisikan arsitektur data, arsitektur aplikasi dan arsitektur teknologi. Arsitektur data menjelaskan jenis-jenis data utama yang diperlukan bagi bisnis. Arsitektur aplikasi mendefinisikan jenisjenis aplikasi yang dibutuhkan untuk mengelola data dan mendukung fungsi bisnis. Arsitektur teknologi mendefinisikan jaringan yang mendukung sistem akademik (Yusuf Miftahudin, 2013).

Panah pada lapisan ini bermakna bahwa arsitektur data didefinisikan sebelumnya, kemudian pendefinisian arsitektur aplikasi, dan terakhir adalah arsitektur teknologi (Yusuf Miftahudin, 2013).

Pada tahapan ini, didefinisikan jenisjenis data utama yang mendukung fungsi bisnis yang telahdidefenisikan jenis-jenis aplikasi utama yang dibutuhkan untuk mengelola data dan mendukung fungsi 
bisnis sistem akademik (Yusuf Miftahudin, 2013).

\subsubsection{Lapaisan IV Strategi Pencapaian}

Pada lapisan ini digunakan sebagai rencana implementasi atau migrasi. Tahapan ini mendefinisikan urutan untuk implementasi aplikasi, jadwal untuk implementasi, analisis biaya dan manfaat, dan mengusulkan jalus untuk migrasi dari kondisi saat ini ke kondisi yang diinginkan (Yusuf Miftahudin, 2013).

\subsubsection{Model Rantai Nilai (Value Chain Analysis) Porter}

Konsep porter's value-added chain membagi fungsi-fungsi utama di organisasi kedalam dua kelompok besar, yaitu aktivitas utama (primary activities) dan aktivitas pendukug (support activities) (Ferly Ardhy, 2015)

Primary activities (kegiatan utama) pada rantai nilai ini adalah sebagai berikut:

1) Inbound Logistic: aktivitas yang berhubungan dengan penerimaan, penyimpanan, dan menyebarkan masukan.

2) Operations: aktivitas yang mentransformasikan masukan menjadi keluaran menjadi produk akhir.

3) Outbound Logistic: aktivitas yang berhubungan dengan menyebarkan produk/jasa ke pelanggan.

4) Marketing \& Sales: kegiatan yang berhubungan dengan pemasaran dan penjualan seperti penelitian pasar, promosi dan sebagainya.
5) Service: kegiatan yang berhubungan dengan penyedia layanan untuk meningkatkan pemeliharaan produk seperti instalasi, pelatihan, perbaikan, suplai bahan dan perawatan.

Support activities (kegiatan pendukung) yang digambarkan Porter adalah sebagai berikut:

1) Firm Infrastucture : merupakan aktivitas, biaya dan aset yang berhubungan denganmanajemen umum, accounting dan keuangan, keamanan dan keselamatan sistem informasi dan fungsi lainnya.

2) Human Resources Management : terdiri dari aktivitas yang terlibat seperti penerimaan, dengar pendapat, pelatihan, pengembangan dan kompensasi untuk semua tipe personil dan mengembangkan tingkat keahlian pekerja.

3) Technology Development : aktivitas yang terkait dengan biaya yang berhubungan dengan produk, perbaikan proses, perancangan perlatan, pengembangan perangkat lunak komputer, sistem telekomunikasi, kapabilitas basis data baru dan pengembangan dukungan sistem berbasis komputer.

4) Procurement : kegiatan yang berhubungan dengan bagaimana sumber daya diperoleh seperti fungsi pembelian input yang digunakan dalam value chain organisasi.

Value Activities

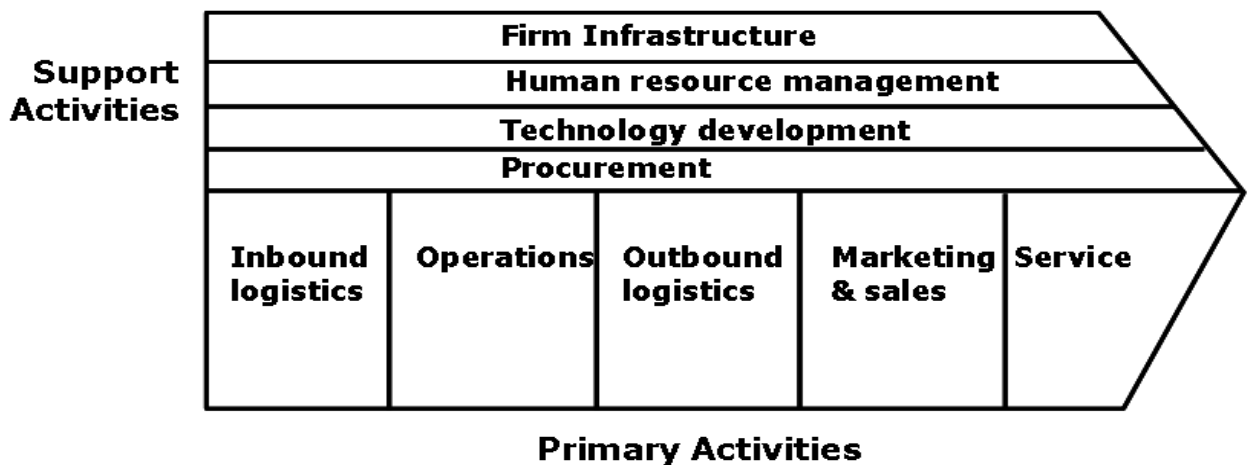

Gambar 3 Value Chain Porter 


\subsubsection{Portopolio Aplikasi}

Analisis aplikasi fortopolio dapat digunakan untuk memetakan arsitektur aplikasi yang dibutuhkan dimasa yang akan datang dalam mendukung fungsi bisnis organisasi/perusahaan (Ward and Peppard, 2002). Pemetaan aplikasi ini dengan empat kuadran (strategic, high potential, key eperation, and support) sesuai kategori penilaian suatu aplikasi terhadap dampaknya pada bisnis. Berikut portofolio yang dimaksud :

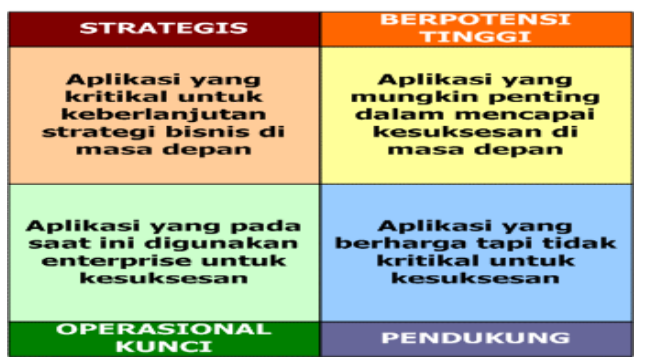

Gambar 4 Portofolio Aplikasi [Ward and Peppard, 2002]

\section{HASIL DAN PEMBAHASAN}

\subsection{Lapisan I EAP Permulaan Inisiasi Perencanaan}

Yang akan dibahas dari tahap awal yang ada pada inisiasi perencanaan adalah untuk menentukan ruang lingkung dan sasaran EAP, Visi dan Misi, Penyesuaian metodelogi.

\section{Proses dari Lapisan I EAP Inisiasi Perencanaan}

Untuk mendapatkan hasil pencarian data proses bisnis yang mencakup seluruh aktivitas dalam bentuk tujuan yang ada pada AMIK DCC Pringsewu perlu dilakukannya indetifikasi stakeholder, identifikasi tugas serta tanggung jawab masing-masing stakeholder untuk mendukung visi dan misi, tujuan dan sasaran strategi organisasi.

\section{Hasil dari Inisiasi Perencanaan}

Berdasarkan tanggung jawab stakeholder, maka fungsi bisnis utama dibuat dalam bentuk rantai nilai sebagai berikut :

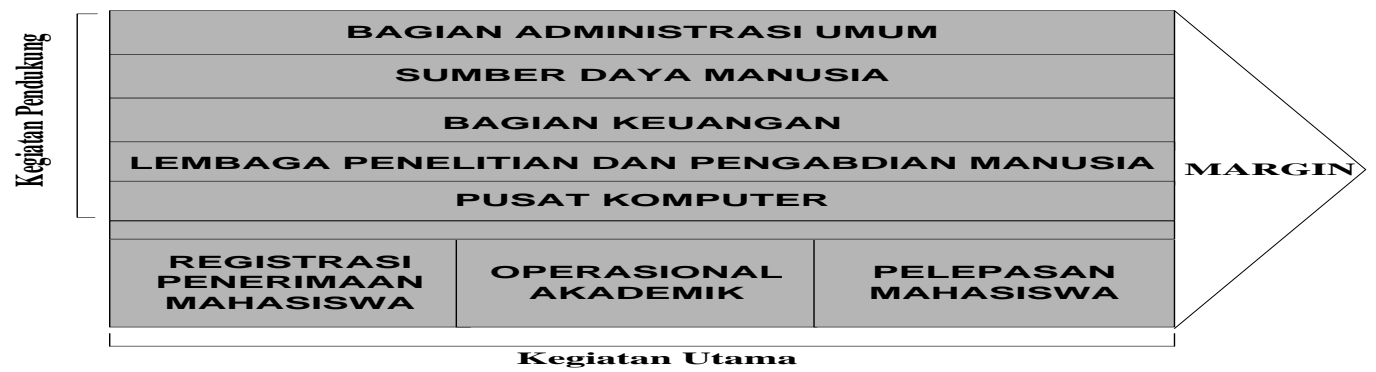

Gambar 5 Rantai Nilai AMIK DCC Pringsewu

Dari masing-masing aktivitas utama (primary activities) dan aktivitas pendukung (support activities) pada Pergruan Tinggi Dian Cipta CendikiaKotabumi dapat diuraikan lagi menjadi beberapa sub aktifitas antara lain :

\section{a. Aktivitas Utama (primary activities)}

1. Registrasi Mahasiswa Baru dan lama Kegiatan yang dilaksanakan adalah penerimaan mahasiswa baru dan pindahan dan validasi pembayaran serta melaksanakan kegiatan ujian seleksi masuk perguruan tinggi hingga melakukan pemeriksaan ujian seleksi masuk mahasiswa baru. Serta registarsi 
mahasiswa lama agar dapat melakukan daftar ulang untuk mengikuti kegiatan belajar mengajar.

2. Proses Operasional Akademik

Pada kegiatan ini dilaksanakan penyelenggaraan kegiatan belajar mengajar mulai dari penetapan kurikulum, penetapan kalender akademik, penawaran matakuliah, bimbingan akademik, pengolahan FRS dan KTM, Penetapan dosen, penyusunan jadwal, pelaporan pelaksanaan matakuliah, pelaksanaan ujian sampai pada pegolahan data nilai.

3. Pelepasan Mahasiswa

Kegiatan ini adalah merupakan tahap akhir dalam pelaksanaan kegitan operasional akademik sampai pada penerbitan ijazah dan transkip nilai yang menandai kegiatan akademik seorang mahasiswa telah berakhir.

b. Aktivitas Pendukung (support activities)

1. Bagian Administrasi Umum

Memiliki kegiatan program perencanaan, pemanfaatan dan melakukan pengembangan terhadap sarana dan prasarana perguruan tinggi AMIK DCC Pringsewu.

2. Sumber Daya Manusia

Memiliki kegiatan perencanaan pengelolaan sumber daya manusia, seperti perekrutan staff yang handal, tenaga dosen yang sesuai dengan kompetensinya hingga melakukan kegiatan beasiswa pendidikan S2 bagi dosen yang berprestasi, perhitungan gaji, perhitungan cuti serta membuat pelaporan rekapitulasi honor dan gaji.

3. Bagian Keuangan

Memiliki kegiatan untuk melakukan perencanaan anggaran dan investasi untuk mendukung operasional perguruan tinggi AMIK DCC Pringsewu.

4. Lembaga Penelitian Dan Pengabdian Masyarakat
Melakukan pendistribusi surat penelitian dosen, perencanaan dan melaksanakan kegiatan peneliti serta pengabdian dosen dan menganggarkan pelaksanaan kegiatan penelitian sehingga seluruh dosen dapat melaksanakan kegiatan penelitian dalam rangka pengembangan ilmu serta dalam rangka melakukan pengabdian terhadap masyarakat.

5. Pusat Laboratorium Komputer

Melakukan pengembangan fasilitas teknologi informasi khususnya laboratorium untuk mengurangi kegiatan akademik dan penelitian dosen.

\subsection{Lapisan II EAP Pemahaman Kondisi Saat ini}

\section{Pemodelan Bisnis}

Tujuan dari pemodelan bisnis ini adalah untuk menentukan model bisnis yang akan dipakai untuk membangun suatu basis pengetahuan mengenai data, proses bisnis, aplikasi dan sistem informasi yang digunakan pada sistem informasi akademik AMIK Pringsewu. Dalam perencanaan Arsitectur Enterprise, pemodelan bisnis dilakukan dalam dua bagian terpisah yaitu bisnis awal yang di ikuti dengan model bisnis lengkap. AMIK DCC Pringsewu memberika pelayanan sebagai berikut :

1. Registrasi Mahasiswa Baru
a. Validasi Pembayaran
b. Pembentukan panitia Penerimaan Mahasiswa Baru (PMB)
c. Penetapan anggaran ujian Penerimaan Mahasiswa Baru (PMB)
d. Penjadwalam Kegiatan Ujian Penerimaan Mahasiswa Baru (PMB)
e. Penyusunan Materi Ujian Penerimaan Mahasiswa Baru (PMB)
f. Pembuatan NPM
g. Mencetak KTM Sementara
h. Laporan Registrasi Mahasiswa baru

1.1. Registrasi Mahasiwa Lama
a. Validasi pembayaran
b. Laporan Registrasi mahasiswa lama

2. Proses Operasional Akademik

a. Penetapan Kurikulum 
b. Penetapan Kalender Akademik

c. Penawaran Mata Kuliah sesuai kurikulum

d. Bimbingan Akdemik

e. Pengolahan Form Rencana Studi

f. Pengelolaan perubahan Form Rencana Studi

g. Pembuatan KRS dan KTM

h. Penetapan Dosen ke mata kuliah

i. Penyusunan jadwal sesual mata kuliah

j. Pelaporan Pelaksanaan Perkuliahan

k. Pelaksanaan Ujian (Quis, UTS, UAS)

1. Penilaian

m. Cuti Akademik Mahasiswa

n. Ujian Kompetensi

o. Pelaporan Akademik

3. Pelepasan Mahasiswa
a. Penetapan syarat kelulusan
b. Penetapan Drop Out
c. Penetapan pengunduran diri
d. Pembuatan ijazah dan traskrip nilai
e. Pelaksanaan wisuda
f. Data Alumni

4. Bagian Administrasi Umum
a. Pengelolaan Sarana dan Prasaran
b. Pengelolaan pengadaan sarana dan prasarana
c. Pengelolaan Invetarisasi Sarana dan Prasarana
d. Pengawasan dan evaluasi pemanfaatan sarana dan prasarana
e. Pemeliharaan rutin sarana dan prasarana
f. Pelaporana sarana dan prasarana

5. Sumber Daya Manusia
a. Penetapan kebijakan Manajemen Rekruitmen
b. Penetapan kebijakan administrasi SDM
c. Manajemen Personil
d. Pengelolaan Perekrutan Kerja

e. Pengelolaan data Personal

f. Perhitungan Gaji

g. Perhitungan Cuti

h. Perhitungan Honor

i. Pengembangan Karir

j. Evaluasi prestasi personal

k. Pelaporan Manajemen SDM

1. Pelaporan Rekapitulasi Honor dan Gaji

6. Bagian Keuangan
a. Penetapan anggrana
b. Pengalokasian anggaran
c. Revisi anggaran
d. Monitoring dan evaluasi anggaran
e. Pembukuan Pelaporan keuangan

7. Lembaga Penelitian dan pengabdian masyarakat
a. Pendistribusian surat penelitian dosen
b. Pelaporan hasil penelitian
c. Pelaporan hasil pengabdian masyarakat
d. Pelaporan administrai keuangan

8. Pusat Laboratorium Komputer
a. Pelaksanaan
administrasi Laboratorium
b. Pelaporan Administrasi Laboratorium
c. Pengembangan software atau sistem informasi

\section{Sistem Dan Teknologi Saat Ini}

Berdasarkan kondisi diatas bahwasanya AMIK Dian Cipta Cendikia Pringsewu belum melakukan proses pengembangan teknologi informasi yang strategis guna mendukung proses bisnis khususnya kegiatan akademik pada AMIK Dian Cipta Cendikia Pringsewu. pemetaan fungsi hubungan antara fungsi bisnis dan teknologi saat ini pada AMIK Dian Cipta Cendikia Pringsewu seperti pada Tabel 3.4 berikut ini.

Tabel 1 Dukungan Fungsi bisnis dan Teknologi saat ini

\begin{tabular}{|l|c|c|}
\hline No & Nama Fungsi Bisnis & Aplikasi \\
\hline $\mathbf{1}$ & Validasi Pembayaran & Menggunakan aplikasi perkantoran \\
\hline $\mathbf{2}$ & Pendataan calon PMB & Menggunakan aplikasi perkantoran \\
\hline $\mathbf{3}$ & Penyusunan anggaran PMB & Menggunakan aplikasi perkantoran \\
\hline
\end{tabular}




\begin{tabular}{|c|c|c|}
\hline 4 & Penyusunan jadwal Ujian PMB & Menggunakan aplikasi perkantoran \\
\hline 5 & Penyusunan jenis seleksi & Menggunakan aplikasi perkantoran \\
\hline 6 & Pelaporan pelaksanaan PMB & Menggunakan aplikasi perkantoran \\
\hline 7 & Pendataan mahasiswa baru & Menggunakan aplikasi perkantoran \\
\hline 8 & Pembentukan Kelas & Menggunakan aplikasi perkantoran \\
\hline 9 & Penentuan Jurusan & Menggunakan aplikasi perkantoran \\
\hline 10 & Pembuatan NPM & Menggunakan aplikasi perkantoran \\
\hline 11 & Pembuatan KTM & Menggunkana aplikasi perkantoran \\
\hline 12 & Penyusunan kalender akademik & Menggunakan aplikasi perkantoran \\
\hline 13 & Penyusunan Kurikulum & Menggunakan aplikasi perkantoran \\
\hline 14 & Pembuatan Form Rencana Studi & Menggunakan aplikasi perkantoran \\
\hline 15 & Pembuatan Perubahan Rencana Studi & Menggunakan aplikasi perkantoran \\
\hline 16 & Pengolahan data dosen dan mahasiswa & Aplikasi perkantoran/jaringan internet \\
\hline 17 & Penyusunan jadwal perkuliahan & Aplikasi perkantoran/jaringan internet \\
\hline 18 & Pembuatan absen mahasiswa & Menggunkana aplikasi perkantoran \\
\hline 19 & Pembuatan absen dosen & Menggunkana aplikasi perkantoran \\
\hline 20 & Penjadwalan Ujian & Menggunkana aplikasi perkantoran \\
\hline 21 & Nilai & Menggunkana aplikasi perkantoran \\
\hline 22 & Pembuatan KHS & Menggunkana aplikasi perkantoran \\
\hline 23 & Pelaporan evaluasi perkuliahan & Aplikasi perkantoran/jaringan internet \\
\hline 24 & Pelaporan mahasiswa aktif \& non aktif & Aplikasi perkantoran/jaringan internet \\
\hline 25 & Bimbingan tugas akhir & Aplikasi perkantoran/jaringan internet \\
\hline 26 & Ujian tugas akhir & Menggunkana aplikasi perkantoran \\
\hline 27 & Pindahan/Konversi & Menggunkana aplikasi perkantoran \\
\hline 28 & Cuti akademik mahasiswa & Menggunkana aplikasi perkantoran \\
\hline 29 & Rencana ujian kompetensi & Aplikasi perkantoran/jaringan internet \\
\hline 30 & Administrasi pengunduran diri & Menggunakan aplikasi perkantoran \\
\hline 31 & Administrasi Drop out & Menggunkana aplikasi perkantoran \\
\hline 32 & Pendataan calon wisuda & Menggunakan aplikasi perkantoran \\
\hline 33 & Pembuatan ijazah \& transkip nilai & Menggunakan aplikasi perkantoran \\
\hline 34 & Pendataan Data Alumni & Menggunakan aplikasi perkantoran \\
\hline 35 & Administrasi bagian umum & Menggunakan anlikasi_perkantoran \\
\hline 36 & Manajemen sumber daya manusia & Menggunakan aplikasi perkantoran \\
\hline 37 & Sistem informasi keuangan & Aplikasi perkantoran/jaringan internet \\
\hline 38 & Pendataan penelitian \& pengabdian masyarakat & Menggunakan aplikasi perkantoran \\
\hline 39 & Pusat laboratorium komputer & Menggunakan aplikasi perkantoran \\
\hline
\end{tabular}

\section{Lapisan III EAP Rencana Masa Depan Arsitektur Data}

Arsitektur data dibuat melalui identifikasi entitas fungsi bisnis dan entitas data yang ada di organisasi. Satu proses bisnis bisa berhubungsn dengan beberapa entutas data, dan sebaliknya beberapa proses bisnis dapat berhubungan dengan satu entitas data.

Tabel 2 Daftar Entitas Data

\section{Entitas Bisnis}

Entitas Penerimaan Mahasiswa

\section{Entitas Data}

1. Entitas Panitia PMB

2. Entitas Soal Ujian PMB

3. Entitas Peserta PMB 


\begin{tabular}{|c|c|}
\hline & $\begin{array}{ll}\text { 4. } & \text { Entitas Jenis Seleksi } \\
\text { 5. } & \text { Hasil Seleksi } \\
\text { 6. } & \text { Laporan PMB } \\
\text { 7. } & \text { Entitas Calon } \\
& \text { Mahasiswa } \\
\text { 8. } & \text { Entitas Jurusan } \\
\text { 9. } & \text { Entitas Kelas } \\
\text { 10. } & \text { Entitas Seleksi } \\
& \text { Diploma }\end{array}$ \\
\hline $\begin{array}{l}\text { Entitas Operasional } \\
\text { Akademik }\end{array}$ & $\begin{array}{l}\text { 11. Entitas Mahasiswa } \\
\text { 12. Entitas Dosen } \\
\text { 13. Entitas Mata Kuliah } \\
\text { 14. Entitas Registrasi } \\
\text { Kuliah } \\
\text { 15. Entitas Program Studi } \\
\text { 16. Entitas Ruang Kuliah } \\
\text { 17. Entitas Jadwal Kuliah } \\
\text { 18. Entitas Absen } \\
\text { Kehadiran Mahasiswa } \\
\text { 19. Entitas Absen } \\
\text { Kehadiran Dosen } \\
\text { 20. Entitas Kurikulum } \\
\text { 21. Entitas Nilai } \\
\text { 22. Entitas Kalender } \\
\text { Akademik } \\
\text { 23. Entitas FRS } \\
\text { 24. Entitas PFRS } \\
\text { 25. Entitas Personil } \\
\text { 26. Entitas Jadwal Ujian } \\
\text { 27. Entitas Cuti } \\
\text { 28. Entitas Dosen } \\
\text { Pembimbing } \\
\text { Akademik } \\
\text { 29. Entitas Registrasi } \\
\text { TA/Skripsi } \\
\text { 30. Entitas Registrasi } \\
\text { Sidang } \\
\text { 31. Entitas Berita Acara } \\
\text { Kuliah } \\
\text { 32. Pindahan/Konversi }\end{array}$ \\
\hline Entitas Pelepasan Mahasiswa & $\begin{array}{l}\text { 33. Entitas Alumni } \\
\text { 34. Entitas Stakeholder } \\
\text { 35. Entitas Wisuda } \\
\text { 36. Entitas Pengunduran } \\
\text { Diri } \\
\text { 37. Entitas Drop Out } \\
\text { 38. Entitas Ijazah/Transkip }\end{array}$ \\
\hline $\begin{array}{l}\text { Entitaas Bagian Administrasi } \\
\text { Umum }\end{array}$ & $\begin{array}{l}\text { 39. Entitas Inventarisasi } \\
\text { Sarana } \\
\text { 40. Entitas Pemeliharaan } \\
\text { Sarana } \\
\text { 41. Entitas Pengadaan }\end{array}$ \\
\hline
\end{tabular}




\begin{tabular}{|l|l|}
\hline & 42. Entitas Monitoring \\
& Aset \\
& 43. Entitas Realisasi \\
\hline Entitas Sumber Daya & 44. Entitas Rekruitmen \\
& 45. Entitas Kehadiran \\
& 46. Entitas Pelatihan \\
& 47. Entitas Honor/Gaji \\
& 48. Entitas Studi Lanjut \\
& 49. Entitas Prestasi \\
& Pegawai \\
& 50. Entitas Calon Pegawai \\
& 51. Entitas Cuti \\
\hline Entitas Bagian Keuangan & 52. Entitas Anggaran \\
& 53. Entitas Realisasi \\
& 54. Entitas Pendapatan \\
& 55. Entitas Pengeluaran \\
56. Entitas Perkiraan
\end{tabular}

\section{Arsitektur Aplikasi}

Arsitektur ini mempunyai tujuan untuk mendefiniksan aplikasi utama yang dibutuhkan untuk mengelola data dan pendukung fungsi bisnis dari enterprise. Aplikasi yang dimaksud adalah proses pendefinisian aplikasi apa saja yang akan mengelola data dan menyediakan informasi untuk pihak manajemen terhadap fungsi bisnisnya. Berikut adalah portopolio aplikasi :

Tabel 3 Portofolio Aplikasi

\begin{tabular}{|l|l|}
\hline STRATEGIS & $\begin{array}{l}\text { BERPOTENSI } \\
\text { TINGGI }\end{array}$ \\
\hline 1. Aplikasi Validasi Pembayaran Mahasiswa & \\
2. Aaru & \\
3. Aplikasi Registrasi Calon Mahasiswa & \\
4. Sistem Rencana Anggaran & \\
5. Aplikasi Pengelolaan Jadwal Ujian & \\
6. Aplikasi Pengelolaan Jadwal Ujian & \\
Tompetensi & \\
7. Sistem Ujian Seleksi Masuk & \\
8. Aplikasi Registrasi Mahasiswa & \\
9. Aplikasi Pelaporan Penerimaan & \\
10. Sistem Kalendar Akademik & \\
11. Aplikasi Registrasi Ulang Mahasiswa & \\
12. Aplikasi Form Rencana Studi & \\
13. Aplikasi Perwalian & \\
14. Aplikasi Penjadwalan Kuliah & \\
15. Sistem Administrasi Kuliah & \\
\hline
\end{tabular}




\begin{tabular}{|c|c|}
\hline $\begin{array}{l}\text { 16. Aplikasi Perubahan Form Rencana Studi } \\
\text { 17. Aplikasi Penjadwalan Ujian } \\
\text { 18. Aplikasi Kelas } \\
\text { 19. Aplikasi Jurusan } \\
\text { 20. Aplikasi Nilai } \\
\text { 21. Aplikasi Manajemen Kurikulum } \\
\text { 22. Aplikasi Kartu Hasil Studi } \\
\text { 23. Aplikasi Skripsi } \\
\text { 24. Aplikasi Bimbingan Skripsi } \\
\text { 25. Aplikasi Cuti Akademik } \\
\text { 26. Aplikasi Pindahan/Konversi } \\
\text { 27. Aplikasi Pelaporan Akademik } \\
\text { 28. Aplikasi Transkrip } \\
\text { 29. Aplikasi Ijazah } \\
\text { 30. Aplikas Alumni } \\
\text { 31. Aplikas Wisuda } \\
\text { 32. Aplikasi AplikasDrop Out } \\
\text { 33. Aplikasi Pengunduran Diri }\end{array}$ & \\
\hline OPERASIONAL KUNCI & PENDUKUNG \\
\hline $\begin{array}{l}\text { 1. Aplikasi Data Karyawan } \\
\text { 2. Aplikasi Studi Lanjut } \\
\text { 3. Aplikasi Kehadiran } \\
\text { 4. Aplikasi Honor/Gaji Karyawan } \\
\text { 5. Aplikasi Realisasi } \\
\text { 6. Aplikasi Pendapatan Dan Pengeluaran } \\
\text { 7. Aplikasi Monitoring Dan Pelaporan } \\
\text { 8. Aplikasi Administrasi Penelitian Dan } \\
\text { Pengabdian Masyarakat } \\
\text { 9. Aplikasi Monitoring Dan Evaluasi Hasil } \\
\text { Penelitian }\end{array}$ & $\begin{array}{ll}\text { 1. } & \text { Aplikasi Inventaris } \\
\text { Sarana } \\
\text { 2. Aplikasi } \\
\text { Pemeliharaan } \\
\text { Sarana } \\
\text { 3. Administrasi } \\
\text { Laboratorium }\end{array}$ \\
\hline
\end{tabular}

\section{Arsitektur Teknologi}
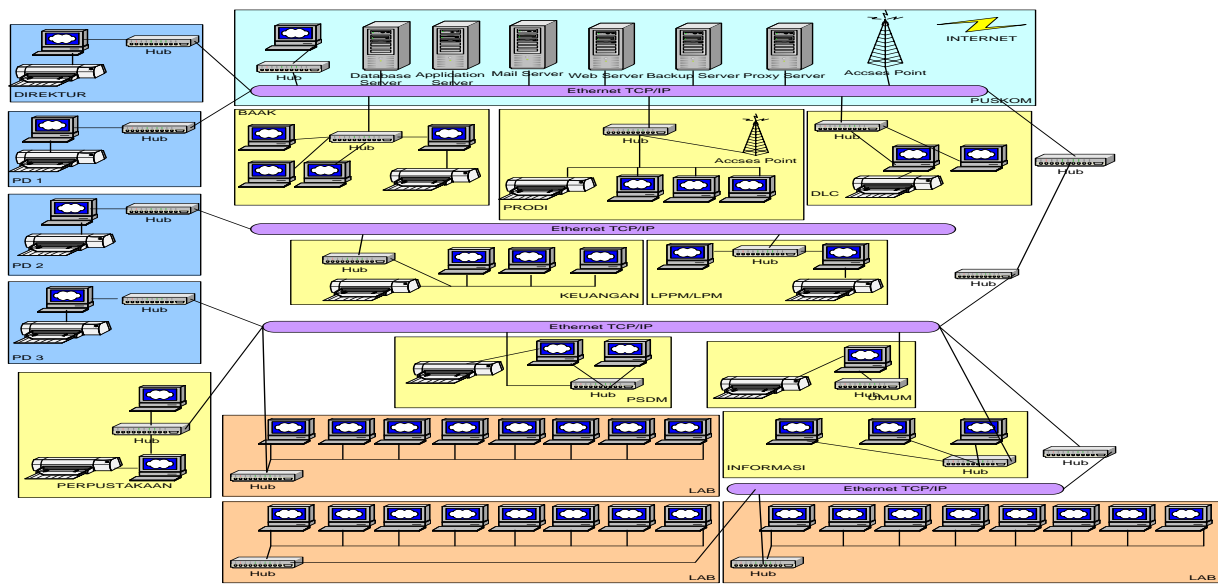

Gambar 6 Konseptual Jaringan enterprise Kampus AMIK DCC Pringsewu

\section{Rencana Implementasi}

Dengan adanya faktor yang mendukung keberhasilan implementasi sistem informasi, maka berikut akan dijelaskan rencana implementasi aplikasi 
Tabel 4 Roadmap Rencana Implementasi

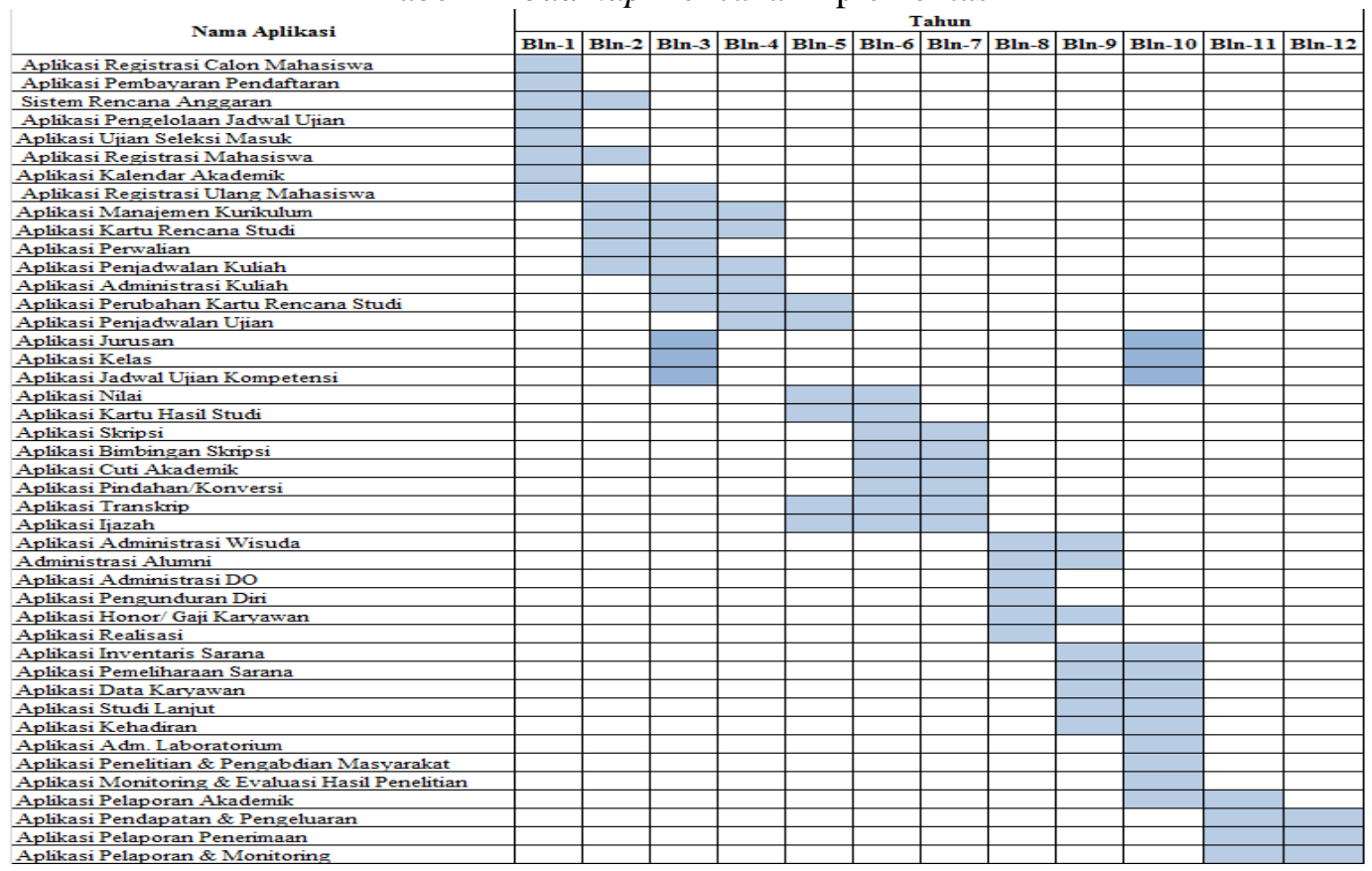

\section{KESIMPULAN}

Berdasarkan hasil penelitian, yang telah dilakukan pada bab-bab sebelumnya, maka dapat diambil beberapa kesimpulan sebagai berikut :

1. Pemanfaatan dan pengembangan SI/TI di AMIK DCC Pringsewu belum terlaksana dengan optimal, hal ini terlihat dari fungsi bisnis yang belum didukung oleh sistem informasi.

2. AMIK DCC Pringsewu belum memiliki sistem pengelolaan sumber daya informasi sebagai salah satu untuk merencanakan pengembangan sistem terintegrasi untuk bidang akademik dan dukungannya.

3. Pelayanan akademik yang dilakukan di AMIK DCC Masih menggunakan Ms. Office dan masih menggunakan fasilitas internet, jadi mahasiswa hanya dapat melihat informasi saja tanpa dapat melakukan kegiatan akademik secara online.

4. Dalam pembuatan rencana strategis sistem informasi dilakukannya studi pendahuluan, latar belakang, rumusan masalah, tujuan masalah dan pengumpulan data yang berupa data primer dan data skunder.
5. Untuk menghasilkan perencanaan strategis sistem informasi penulis melakukan beberapa tahapan yaitu : Permulaan inisiasi perencanaan, Pemahaman kondisi saat ini, Rencana masa depan, Rencana implementasi.

6. Pemodelan bisnis utama pada AMIK DCC Pringsewu digambarkan pada value chain yang memiliki aktivitas utama yaitu Registrasi penerimaan mahasiswa, operasional akademik dan Pelepasan mahasiswa.

7. Dengan adanya rencana strategis sistem informasi pada AMIK DCC Pringsewu diharapkan proses bisnis dapat berjalan dengan baik dan semua data dapat terintegrasi, dan mahasiswa dapat mendapatkan pelayanan akademik secara online.

8. Hasil pendefinisian terhadap arsitektur enterprise pada AMIK DCC Pringsewu memiliki 61 Entitas dan 45 usulan kandidat aplikasi yang nantinya bisa jadi acuan untuk pembuatan sistem informasi akademik.

\section{SARAN}

Berikut adalah saran bagi pengembanganya : 
1. Merencanakan kegiatan pengembangan sistem informasi sesuai dengan portopolio aplikasi yang telah disusun

2. Bahwa sistem ini dapat dikembangkan lebih lanjut, terutama pada tahap implementasi sistem informasi berdasarkan prioritas aplikasi yang

\section{Daftar Pustaka}

Yeni Kustiyaningsih, 2007, Perencanaan Arsitektur Enterprise Berbasis Web Pada Institusi Pendidikan Tinggi, Seminar Nasional Teknologi 2007 (SNT 2007), ISSN : 1978-9777, 24 November 2007, Yogyakarta

Agustono Heriadi, M. Suyanto dan Sudarmawan, 2014, Perencanaan Strategi Sistem Informasi STMIK Surya Kediri, Citec Journal, ISSN : 2354-5771, Vol. 1 No. 1, Januari 2014

Ahmad Khumaidi, Agus Suryana dan Eka Ridhawati, 2016, Perencanaan Strategi Sistem Informasi Dan Teknologi Informasi Pada STMIK Pringsewu Dengan Menggunakan Metodologi Enterprise Architecture Planning (EAP), Seminar Nasional Teknologi dan Multimedia 2016, ISSN : 2302-3805, Februari 2016, STMIK AMIKOM Yogyakarta

Roni Yunis dan Kridanto Surendro, 2009, Perancangan Model Enterprise Architecture dengan Togaf Architecture Development Method, Seminar Nasional Aplikasi Teknologi Informasi 2009 (SNATI 2009), ISSN : 1907-5022, Yogyakarta

Rommi Kaestria, 2016, Perencanaan Strategi Sistem Informasi Pada Sekolah Tinggi Komputer, Journal Speed - Sentra Penelitian Engineering dan Edukasi, Vol 3 No. 3, ISSN : 1979-9330

Wahyudin, Asep, 2009 Penyelarasan Lingkungan ICT Dengan Kebutuhan Organisasi Sebagai Pendukung Perencanaan Strategi Bagi Perusahaan, Jurnal Pendidikan Informasi Dan Komunikasi, Vol. 2, No. 1, ISSN : 1979-9264 disesuaikan dengan anggaran dana institusi AMIK DCC Pringsewu

3. Sistem ini bisa di review kembali secara bertahap atau dikembangkan lagi lebih detail sesuai dengan kebutuhan AMIK DCC Pringsewu.

Erwin Budi Setiawan, 2009, Pemilihan EA Framework, Seminar Nasional Aplikasi Teknologi Informasi, Yogyakarta 20 Juni 2009, ISSN : 1907-5022

Ferly Ardhy, 2015, Enterprise Architecture Planning (EAP) Dalam Penyusunan Perancangan Sistem Informasi Akademik Yang Terintegrasi, Jurnal Informasi Dan Komputer, Vol. 1, No. 1, ISSN :2337-8344

\section{PUSTAKA BUKU}

O'Rouke, Coral., 2003, Enterprise Architecture Using The Zachman Framework, Thomson, Canada

Spewak, Steven H., Steven C, Hill.,1992, Enterprise Architecture Planning : Developing A Blue Print For Data, Application And Technology, Jonh Willey \& Sons, New York

Rangkuti, F., 2003, Analisis SWOT Teknik Membedah Kasus Bisnis, PT. Gramedia Pustaka Utama, Jakarta

Porter, Michael E., 2003, Competitive Advantage, Creating And Suitaining Superior Perfomance for Analyzing Industries And Competitor, Free Press, New York

Amik Dian Cipta Cendikia, 2016, Panduan Akademik TA 2016-2017, Yayasan Dian Cipta Cendikia, Pringsewu 
